\title{
Are Prospective Counsellors Able to Listen Emphatically? (A Study among Counselling University Students in Indonesia)
}

\author{
Dedy Surya ${ }^{凶}$ \\ Department of Islamic Guidance Counseling, IAIN Langsa, Indonesia \\ email: dedysurya@iainlangsa.ac.id
}

First received:
24 April 2021

Revised:
26 May 2021

Final Accepted:

28 June 2021

\begin{abstract}
Listening ability determines the success of counselling sessions. Counsellors must be able to listen to the various problems presented by their participants wholeheartedly. This research aims to illustrate the ability of emphatic listening among counselling students in Indonesia. This descriptive quantitative study involved 318 participants $(88.7 \%$ women) aged $18-23$ years $(M=19.24, S D=1.108)$ voluntarily selected through convenience sampling. The emphatic listening skills were measured using The Active-Emphatic Listening Scale by Bodie (2011) using Google Form. Based on statistical analysis, it was found that empathic listening to counselling students was classified as high. The study also argues that there are differences in empathy listening skills based on the environment in which they live. At the same time, differences in sex, age, and study year did not determine differences in listening empathetically. This study confirmed that the environment in which a person grows up has implications for empathy.
\end{abstract}

Keywords: communication; counselling; empathy, empathic listening, Indonesian university students

\begin{abstract}
ABSTRAK
Kemampuan mendengarkan mendeterminasi keberbasilan sesi konseling. Para counselor harus mampu untuk. mendengarkan berbagai permasalahan yang disampaikan oleb konselinya dengan sepenub hati. Penelitian ini bertujuan untuk menggambarkan kemampuan emphatic listening among counseling students in Indonesia. Penelitian kuantitatif deskriptif ini melibatkan 318 partisipan (88,7\% wanita) dengan umur berkisar 18-23 tabun (M=19,24 SD=1,108) yang dipilih secara sukarela melalui convenience sampling. The emphatic listening skills diukur dengan menggunakan The Active-Emphatic Listening Scale oleh Bodie (2011) dengan menggunakan Google Form. Berdasarkan analisis secara statistika ditemukan babwa empathic listening mahasiswa konseling tergolong tinggi. Penelitian ini juga berargumentasi bahwa terdapat perbedaan keterampilan empathy listening berdasarkan lingkungan tempat tinggal. Sementara perbedaan jenis kelamin, umur, dan year of study tidak menentukan perbedaan kemampuan mendengar secara empati. Penelitian ini mengonfirmasi bahwa lingkungan tempat seseorang tumbuh dewasa berimplikasi pada kemampuan berempati.
\end{abstract}

Kata kunci : komunikasi; konseling; empati; empathic listening, mahasiswa Indonesia

\section{INTRODUCTION}

Listening ability is one of the central issues in communication. Good listening skills are positively associated with communication skills (Davenport Sypher, Bostrom, \& Hart Seibert, 1989; Yavuz \& Celik, 2017). In communicating, empathy is a core competency for improving interpersonal communication skills (Cuny, Wilde, \& Stephenson, 2012). That is, for someone who can empathize, then interpersonal relationships in communicating will be well established. In some studies, the listening ability is also one of the predictors of success in a group (Eggenberger, 2021; Lloyd, Boer, \& Voelpel, 2015) and success in engaging workers (Jonsdottir \& Kristinsson, 2020).

Like other jobs that rely on communicating, counsellors must also have good listening skills to carry out their duties. Listening is a fundamental ability that counsellors should have 
(Berven \& Bezyak, 2015). The ability to listen from a counsellor has implications for the effectiveness of communicating (Johnson \& Pugach, 2004). Furthermore, the power of counsellors in active listening is able to reduce anxiety experienced by the community (Levitt, 2002).

Empathetic listening skills are essential social skills (Gearhart \& Bodie, 2011) for anyone, especially for counsellors who serve as therapists, because empathy is the basis of healing (Slattery \& Park, 2020). Counsellors who empathize are more successful in dealing with their clients' problems (Moyers \& Miller, 2013). Furthermore, empathic listening impacts the quality of interpersonal relationships (Petersen, 2019). Thus, the ability to listen empathetically becomes a fundamental skill that counsellors must possess, including counselling university students as prospective counsellors in the future.

Scholars have widely highlighted studies related to empathy in communicating. Kelley \& Kelley (2013), through their training, teaches empathy and compassion in communication. Gearhart \& Maben (2021) reviews empathic listening that occurs through social media. Some researchers are trying to unearth predictor variables of empathic listening, such as altruism (Marcu, 2020), communication styles (Brown et al., 2011), and personality (Pence \& Vickery, 2012; Sims, 2017). Some researchers traced the influence of personal and occupational factors (Kourmousi et al., 2018) and sex (Pence \& James, 2015) on empathic listening levels. However, studies that looked at differences in empathic listening levels reviewed from other internal and external factors have not been done, especially in counsellors, including prospective counsellors. The study investigated differences in empathic listening in prospective counsellors based on sex, age, the environment of residence, and study year.

\section{RESEARCH METHOD}

The study included 318 counselling university students in Indonesia ( $11.3 \%$ male, $88.7 \%$ female) aged $18-23$ years $(M=19.24, S D=1.108)$. Participants involved in the study were recruited through convenience sampling using social media and personal contacts. Voluntarily, participants filled out an online survey with Google Form distributed for one month from 1 March to 31 March 2021.

The instrument used in the online survey is The Active-Emphatic Listening Scale (AELS) which was preceded by several questions related to demographic information such as sex, age, residential environment (rural, urban, and coastal), as well as years of study (freshmen, sophomores, junior and senior). AELS is a self-report questionnaire consisting of 11 statement items to measure empathic listening levels through 3 main aspects: sensing, processing, and responding (Bodie, 2011). AELS has high reliability $(\mathrm{r}=0.70)$ with convergent validity with a good empathy scale (Drollinger, Comer, \& Warrington, 2006). The data that has been collected is analyzed using descriptive statistics using Jamovi statistical software (2020). Statistical frequency data were displayed to show demographic characteristics, and the level of empathy participants showed through the scale. In order to see the differences in empathic listening ability levels based on sex, the data were analyzed using an independent sample t-test. In comparison, data based on age, place of residence, and study year were analyzed through Anova.

\section{RESULT AND DISCUSSION}

By comparing empirical scores with hypothetic scores, it was found that, in general, counselling students had high empathy $(41.5 \%)$ and very high $(37.7 \%)$ when listening to their interlocutor. Further results are presented in Figure 1 below. 


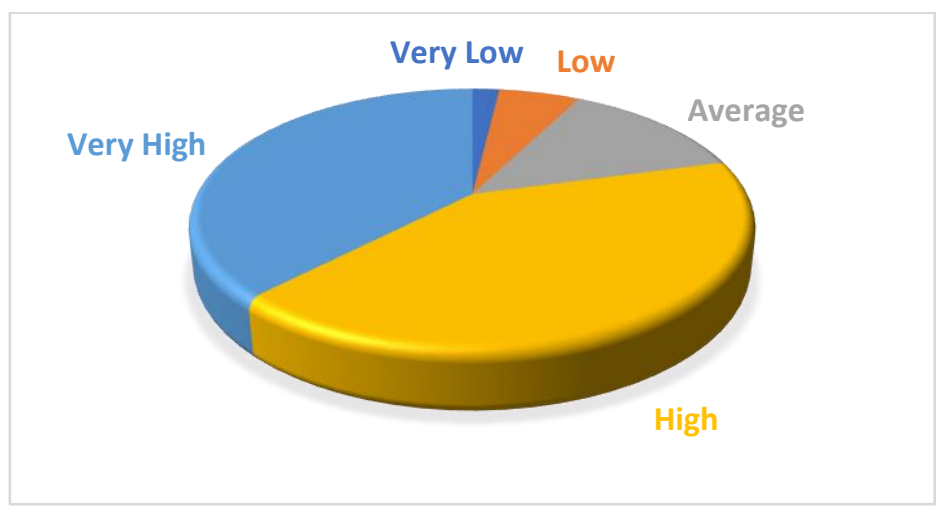

Figure 1 Level of Empathic Listening

This finding assumes that empathic listening ability is at a high level because, in their education, counselling students are equipped with adequate knowledge about the psychological characteristics of a person as a provision of a career in the future. This knowledge has implications for the emergence of empathic behaviour when listening to the communicant. These findings also corroborate a study conducted by Kourmousi et al. (2018) which states that work background affects empathy levels.

Table 1 below shows descriptive statistics of empathic listening levels by sex. The independent t-test test showed an insignificant difference in empathic listening skills between men and women $(t(316)=1.87, p=0.06)$. The female students performed empathic listening slightly higher $(M=57.1, S D=11.2)$ than male students $(M=53.5, S D=9.83)$.

Table 1 T-test Result of Empathic Listening based on sex

\begin{tabular}{cccccc}
\hline Variable & $\begin{array}{c}\text { Mean } \\
\text { Difference }\end{array}$ & Mean & t & SD & p-value \\
\hline AESL & -3.65 & & 1.87 & - & 0.062 \\
Male & & 53.5 & - & 9.83 & - \\
Female & & 57.1 & - & 11.2 & - \\
\hline
\end{tabular}

The results of Pence \& James's study (2015), which showed the influence of sex on empathic listening, were corrected and clarified by finding that empathic listening ability is not significant based on sex differences.

In the ANOVA test shown in Table 2, researchers found a significant difference in empathic listening ability between ages $(F=9.64, p<0.01)$. However, such significant differences did not show that increased lifespan was associated positively or negatively with empathic listening. It was further seen that the empathy of 18 -year-old students $(M=61.3, S D=6.97)$ and 22-year-olds $(M=61.3, S D=5.47)$ had identical empathy scores.

Table 2 ANOVA Result of Empathic Listening based on age

\begin{tabular}{llllll}
\hline Variable & Mean Square & Mean & SD & F & p-value \\
\hline Age & 1037 & & & 9.64 & $<0.001$ \\
18 years & & 61.3 & 6.97 & & \\
19 years & & 49.4 & 11.09 & & \\
20 years & 56.9 & 11.60 & & \\
21 years & 60.1 & 9.80 & & \\
22 years & 61.3 & 5.47 & & \\
23 years & 52.0 & 3.10 & & \\
\hline
\end{tabular}

The difference in residence has implications for differences in empathic listening $(F=8.77$, $p<0.001)$. In Table 3, the data showed that students living in urban areas had higher empathy $(M=59.2, S D=10.7)$ than students domiciled in rural areas $(M=54.4, S D=11.3)$ and coastal $(M=52.0, S D=4.45)$. Knafo, Zahn-Waxler, Van Hulle, Robinson, \& Rhee (2008) supported these results, finding environmental influences on empathy. 
Table 3 ANOVA Result of Empathic Listening based on environment

\begin{tabular}{llllll}
\hline Variable & Mean Square & Mean & SD & F & p-value \\
\hline Environment & 1022 & & & 8.77 & $<0.001$ \\
Urban & & 59.2 & 10.7 & & \\
Rural & & 54.4 & 11.3 & & \\
Coastal & & 52.0 & 4.45 & & \\
\hline
\end{tabular}

In Table 4, researchers found a significant difference in empathic listening ability between years of study $(F=8.84, p<0.01)$. However, these significant differences did not show that the increase in the year of study was positive or negative with empathic listening. The lowest empathy level is the sophomore $(M=51.3, S D=12.27)$, while the highest is junior $(M=59.0$, $S D=9.65)$.

Table 4 ANOVA Result of Empathic Listening based on Study Year

\begin{tabular}{llllll}
\hline Variable & Mean Square & Mean & SD & F & p-value \\
\hline Study Year & 1009 & & & 8.86 & $<0.001$ \\
Freshmen & & 53.5 & 12.05 & & \\
Sophomore & & 51.3 & 12.27 & & \\
Junior & & 59.0 & 9.65 & & \\
Senior & & 58.4 & 10.30 & & \\
\hline
\end{tabular}

At first glance, these findings contradict the research of DiLalla, Hull, \& Dorsey (2004) explained that exposure to activity in empathy in educational settings affects empathy ability. However, we can easily understand that the year of study does not always correlate positively directly with exposure to activity related to empathy.

\section{CONCLUSION}

Conclusively, empathic listening is associated with many factors, both internal and external. Prospective jobs affect the high ability to empathize when listening to others. The study confirmed empathic listening differences based on differences in residence, but not for sex, age, and year of study. The absence of such differences can be caused by several other factors that are not analyzed, such as personality, intelligence levels, and other psychological factors. In addition, the use of self-report instruments also allows subjectivity and inaccuracies. The study recommends further tracing involving various other factors so that variable empathic listening can be comprehensively understood.

\section{BIBLIOGRAPHY}

Berven, N. L., \& Bezyak, J. L. (2015). Basic counselling skills. In F. Chan, N. L. Berven, \& K. R. Thomas (Eds.), Counseling theories and techniques for rehabilitation and mental bealth professionals (2nd ed., pp. 227-245). New York: Springer Publishing Co Inc.

Bodie, G. D. (2011). The Active-Empathic Listening Scale (AELS): Conceptualization and evidence of validity within the interpersonal domain. Communication Quarterly, 59(3), 277295.

Brown, T., Boyle, M., Williams, B., Molloy, A., Palermo, C., McKenna, L., \& Molloy, L. (2011). Predictors of empathy in health science students. Journal of Allied Health, 40(3), 143-149.

Cuny, K. M., Wilde, S. M., \& Stephenson, A. V. (2012). Empathetic listening to build relationships at the center. In E. L. Yook \& W. Atkins-Sayre (Eds.), Communication Centers 
and Oral Communication Programs in Higher Education: Advantages, Challenges, and New Directions (pp. 249-256). Lanham, MD: Lexington.

Davenport Sypher, B., Bostrom, R. N., \& Hart Seibert, J. (1989). Listening, Communication Abilities, and Success at Work. Journal of Business Communication, 26(4), 293-303. https://doi.org/10.1177/002194368902600401

DiLalla, L. F., Hull, S. K., \& Dorsey, J. K. (2004). Effect of Gender, Age, and Relevant Course Work on Attitudes Toward Empathy, Patient Spirituality, and Physician Wellness. Teaching and Learning in Medicine, 16(2), 165-170. https://doi.org/10.1207/s15328015tlm1602_8

Drollinger, T., Comer, L. B., \& Warrington, P. T. (2006). Development and validation of the active empathetic listening scale. Psychology \& Marketing, 23, 161-180. https://doi.org/10.1002/ mar.20105

Eggenberger, A. L. B. (2021). Active listening skills as predictors of success in community college students. Community College Journal of Research and Practice, 45(5), 324-333. https://doi.org/10.1080/10668926.2019.1706667

Gearhart, C. C., \& Bodie, G. D. (2011). Active-empathic listening as a general social skill: Evidence from bivariate and canonical correlations. Communication Reports, 24(2), 86-98. https://doi.org/10.1080/08934215.2011.610731

Gearhart, C. C., \& Maben, S. K. (2021). Active and empathic listening in social media: What do stakeholders really expect. International Journal of Listening, 35(3), 166-187. https://doi.org/10.1080/10904018.2019.1602046

Johnson, L. J., \& Pugach, M. C. (2004). Listening skills to facilitate effective communication. Counseling and Human Development, 36(6), 1-8.

Jonsdottir, I. J., \& Kristinsson, K. (2020). Supervisors' active-empathetic listening as an important antecedent of work engagement. International Journal of Environmental Research and Public Health, 17(21), 7976. https://doi.org/10.3390/ijerph17217976

Kelley, K. J., \& Kelley, M. F. (2013). Teaching Empathy and Other Compassion-Based Communication Skills. Journal for Nurses in Professional Development, 29(6), 321-324. https://doi.org/10.1097/01.NND.0000436794.24434.90

Knafo, A., Zahn-Waxler, C., Van Hulle, C., Robinson, J. L., \& Rhee, S. H. (2008). The developmental origins of a disposition toward empathy: Genetic and environmental contributions. Emotion, 8(6), 737-752. https://doi.org/10.1037/a0014179 
Kourmousi, N., Kounenou, K., Yotsidi, V., Xythali, V., Merakou, K., Barbouni, A., \& Koutras, V. (2018). Personal and job factors associated with teachers' active listening and active empathic listening. Social Sciences, 7(7), 117. https://doi.org/10.3390/socsci7070117

Levitt, D. H. (2002). Active Listening and Counselor Self-Efficacy. The Clinical Supervisor, 20(2), 101-115. https://doi.org/10.1300/J001v20n02_09

Lloyd, K. J., Boer, D., \& Voelpel, S. C. (2015). From listening to leading: Toward an understanding of supervisor listening within the framework of Leader-Member Exchange Theory. International Journal of Business Communication, 54(4), 431-451. https://doi.org/10.1177/2329488415572778

Marcu, G. M. (2020). Self-reported altruism as predictor for active-empathic listening skills. COUNS-EDU: The International Journal of Counseling and Education, 5(1), 23-28. https://doi.org/10.23916/0020200525810

Moyers, T. B., \& Miller, W. R. (2013). Is low therapist empathy toxic? Psychology of Addictive Behaviors, 27(3), 878-884. https://doi.org/10.1037/a0030274

Pence, M. E., \& James, T. A. (2015). The Role of Sex Differences in the Examination of Personality and Active-Empathic Listening: An Initial Exploration. International Journal of Listening, 29(2), 85-94. https://doi.org/10.1080/10904018.2014.965390

Pence, M. E., \& Vickery, A. J. (2012). The roles of personality and trait emotional intelligence in the active-empathic listening process: Evidence from correlational and regression analyses. International Journal of Listening, 26(3), 159-174. https://doi.org/10.1080/10904018.2012.712810

Petersen, A. C. (2019). Empathic listening: Empowering individuals as leaders. The Journal of Student Leadership, 3(2), 63-71.

Sims, C. M. (2017). Do the Big-Five Personality Traits predict empathic listening and assertive communication? International Journal of Listening, 31(3), 163-188. https://doi.org/10.1080/10904018.2016.1202770

Slattery, J. M., \& Park, C. L. (2020). Empathic counseling: Building skills to empower change (2nd ed.). Washington DC: American Psychological Association.

Yavuz, F., \& Celik, O. (2017). The importance of listening in communication. Global Journal of Psychology Research: New Trends and Issues, 7(1), 8-11. https://doi.org/10.18844/gjpr.v7i1.2431 